AL-URBAN: Jurnal Ekonomi Syariah dan Filantropi Islam

Vol. 3, No. 2, Desember 2019

http://journal.uhamka.ac.id/index.php/al-urban

p-ISSN: 2580-3360 e-ISSN: 2581-2874

DOI: $10.22236 /$ alurban_vol3/is2pp203-226

Hal 203-226

\title{
ANALISIS STRATEGI PEMBERDAYAAN EKONOMI DENGAN PENDEKATAN USG DAN SWOT
}

\author{
Yurianto \\ Universitas Muhammadiyah Prof. DR. HAMKA \\ Email: yurimerdeka @gmail.com
}

Diterima: 8 Oktober 2019; Direvisi: 23 November 2019; Disetujui: 21 Desember 2019

\begin{abstract}
The mosque in the history of Islamic civilization is a means to do da'wah and the development of Muslim economic resources. The purpose of this study is to identify the economic potential of the Nurul Iman Mosque, then to analyze the economic potential of the Nurul Iman Mosque in the economy, and to develop strategies in developing the mosque's economy. This study was conducted in a descriptive qualitative approach. The location of Nurul Iman Mosque is very strategic for business activities for the people. The most dominant factor in the economic development of a mosque is a factor in the large number of worshipers. With the cartesius diagram, it is concluded that the grand strategy in the framework of economic development of the Nurul Iman Mosque is the Strength and Opportunity (Strategy $\mathrm{S}-\mathrm{O}$ ) strategy.
\end{abstract}

Keyword: Empowerment, Economic, USG, SWOT, Nurul Iman Mosque

\begin{abstract}
Abstrak
Masjid dalam sejarah peradaban Islam merupakan sarana untuk melakukan dakwah dan pengembangan sumber daya ekonomi umat Islam. Tujuan kajian ini adalah mengidentifikasi potensi ekonomi Masjid Nurul Iman. menganalisis potensi ekonomi Masjid Nurul Iman dalam perekonomian, dan menyusun strategi dalam pengembangan ekonomi masjid. Kajian ini dilakukan secara pendekatan kualitatif deskriptif. Lokasi Masjid Nurul Iman sangat strategis untuk kegiatan bisnis untuk umat. Faktor kekuatan yang paling dominan dalam pengembangan ekonomi masjid adalah faktor banyaknya jumlah jamaah. Dengan diagram kartesius diperoleh kesimpulan bahwa strategi besar dalam rangka pengembangan ekonomi Masjid Nurul Iman adalah strategi Strength dan Opportunity (Strategy S-O).

Kata Kunci: Pemberdayaan, Ekonomi, USG, SWOT, Masjid Nurul Iman
\end{abstract}




\section{PENDAHULUAN}

Salah satu aspek sentral dalam pembangunan bangsa adalah mewujudkan kesejahteraan umum, dan keadilan sosial. Hal ini merupakan tanggung jawab kolektif seluruh pemangku kepentingan pembangunan bangsa. Ini artinya bahwa semua komponen bangsa tanpa terkecuali harus ikut aktif berkontribusi dalam mewujudkan cita cita tersebut secara profesional dan proporsional. Dalam kontek ini keberadaan masjid menjadi sentral. Alasannya adalah bahwa masjid merupakan salah satu pemangku kepentingan pembangunan utama. Ini karena bahwa masjid merupakan perwujudan aspirasi umat Islam sebagai tempat ibadah. Hal ini yang mendasari bahwa masjid menduduki fungsi sentral dan strategis. Untuk itulah fungsi ini perlu dibina sebaik-baiknya, baik segi fisik bangunan maupun segi kegiatan pemakmurannya (Ramadhan, Idaul dan Rahmad, 2019).

Berkaitan dengan hal ini, maka dapat disimpulkan bahwa masjid merupakan lembaga yang mempunyai fungsi yang strategis dalam mewujudkan kesejahteraan umum dan keadilan sosial dalam kerangka kemakmuran masjid. Masjid juga merupakan pusat kegiatan ibadah umat, baik ibadah mahdlah, sosial, pendidikan, ekonomi, kesehatan dan lain sebagainya (Supriyadi, 2017). Jadi secara fungsi masjid mempunyai tugas yang sangat penting dan strategis dalam pembangunan umat. Menurut Darodjat dan
Wahyudiana (2014) secara peruntukannya Masjid tidak hanya berfungsi untuk ibadah, khususnya shalat dengan segala rangkaiannya, masjid juga berfungsi sebagai sarana sosial-seperti pendidikan, pengajian dan kegiatan sosial lainnya- dan juga berfungsi politis-yaitu sebagai pusat pemerintahan, administrasi negara dan tempat berlangsungnya berbagai permusyawaratan bidang politik (Ensiklopedi Hukum Islam, 2000: 1120).

Jumlah masjid secara total tidak kurang dari 700 ribu masjid menurut Dewan Masjid Indonesia dalam Muslim (2014). Menurut hasil studi Muslim bahwa manajemen masjid telah mampu mengoperasikan tahapan dalam memberdayakan ekonomi lokal. Hal ini dilakukan dengan pertama, membangun manajemen, seperti membangun persepsi stakeholders mengenai fungsi masjid, mengelola masjid sesuai dengan manajemen modern, dan mimpi membangun kesuksesan. Kedua, menerapkan prinsip-prinsip manajemen, seperti melayani jama'ah, membuat inovasi dan kreativitas bagi mereka, memberikan dan meningkatkan jama'ah di masjid. Ketiga, memilih strategi yang tepat, seperti mulai melakukan hal yang sederhana dan mudah, serta mempertimbangkan kepentingan organisasi. Namun berdasarkan kondisi riil bahwa menurut Nuriyanto (2018) masjid yang ada hanya berfungsi sebagai tempat ibadah ritual (mahdhah) saja dan 
hanya sebagian kecil yang memfungsikan masjid sebagai ibadah sosial yang luas (ghair mahdhah). Untuk itu optimalisasi pemberdayaan masjid kearah yang lebih berdampak pada masyarakat luas seperti pembinaan sosial ekonomi perlu dikembangkan.

Hal ini sejalan dengan Dalmeri (2014) bahwa Masjid dalam sejarah peradaban Islam merupakan sarana untuk melakukan dakwah dan pengembangan sumber daya ekonomi umat Islam. Ditambah lagi Asshiddiqie (2019) bahwa dalam kontek pengembangan masjid disarankan agar umat membuat halaqah rutin di masjid untuk mendiskusikan tentang pengembangan ekonomi umat Islam (REPUBLIKA.CO.ID, 2019). Selanjutnya diuraikan bahwa masjid harus memberikan sinarnya, membimbing secara moral supaya dinamika ekonomi di pasar itu tumbuh berkembang untuk kemanusiaan. Jadi perlu dikembangkan bahwa di mana ada masjid maka perlu dipikirkan bagaimana pengembangan pasar. Dengan demikian diharapkan mengembangkan ekonomi umat dan ekonomi bangsa, jangan jauh dari masjid. Salah satu keuntungan dalam hal ini menurut Suryanto and Saepulloh (2016) adalah bahwa kemandirian ekonomi umat dapat terbangun dan selanjutnya dapat mengurangi kemiskinan umat.

Selain itu, bahwa fungsi masjid secara sosial sangat tinggi intensitasnya. Untuk itu dibutuhkan dana operasional yang cukup besar. Oleh karena itu, pengembangan ekonomi masjid menjadi suatu keniscayaan agar kegiatan masjid dapat berjalan dengan baik dan bermanfaat secara optimal. Hal ini didasarkan bahwa dalam pengelolaan masjid termasuk dalam pemberdayaan ekonomi harus tetap professional. Selain itu harus dilakukan komunikasi yang efektif baik dengan jamaah maupun stakeholder yang lain (Ridwanullah dan Dedi, 2018).

Pemberdayaan dan pengembangan ekonomi masjid telah banyak memberikan manfaat kepada umat. Penelitian yang dilakukan oleh Aisyah (2013) menemukan bahwa usaha untuk memperkuat ekonomi masjid telah didirikan melalui berbagai usaha seperti pangkas rambut, balai pengobatan, penitipan alas kaki, Bank Perkreditan rakyat, bimbingan haji dan umrah, parkir kendaraan, Baitul Mal, toko buku, toko perlengkapan sablon. Usaha bisnis sangat bervariatif dan ini menunjukkan bahwa masjid mempunyai potensi ekonomi. Fungsi masjid mempunyai potensi dalam kegiatan usaha ekonomi.

Dengan kondisi seperti diuraikan di atas, maka konsep pengembangan perekonomian masjid untuk meningkatkan kemakmuran masjid menjadi suatu konsep yang strategis dan penting. Oleh karena itu maka gerakan masyarakat untuk kemakmuran masjid dalam berbagai aspek perlu dirancang dan difomulasikan dengan baik dan tepat agar kemakmuran masjid dapat terwujud.

Dalam hal ini Allah swt. berfirman: 
"Sesungguhnya yang memakmurkan masjid Allah hanyalah orang orang yang beriman kepada Allah dan hari kemudian, serta (tetap) melaksanakan salat, menunaikan zakat dan tidak takut (kepada apapun) kecuali kepada Allah. Maka mudah mudahan mereka termasuk orang orang yang mendapat petunjuk” Q.S. :9 (At Taubah): 18. Dalam Almumayyaz, Al Quran Tajwid Warna, Transliterasi Per Kata, Terjemah Per Kata.

Dalam hal ini Ali (2012), menjelaskan bahwa ayat tersebut mengandung arti bahwa memakmurkan atau memberdayakan masjidmasjid Allah adalah kewajiban seorang mukmin dan sebagai bukti orang beriman secara paripurna. Jadi ini merupakan suatu kewajiban. Dalam konteks ini Mutholib (2018) berpendapat bahwa eksistensi masjid juga tidak bisa dipisahkan dari kehidupan umat Islam. Dengan dasar ini maka masjid harus dikelola secara baik dan efektif supaya dapat berfungsi secara optimal. Ini artinya bahwa masjid dapat berfungsi sebagai lembaga keagamaan dan sosial kemasyarakatan.

Dalam hal pemberdayaan ekonomi berbasis masjid menurut Supriyadi (2017) bahwa dalam pemberdayaan umat dapat memfokuskan pada program pemberdayaan disesuaikan dengan ciri khas daerah masingmasing. Dana infak dapat digunakan untuk modal bergulir dalam bentuk pinjaman kepada jamaah dengan persyaratan yang sangat ringan tanpa bunga dan agunan bermodal kepercayaan antra pengurus dengan mustahik. Ini salah satu unit bisnis yang dapat dikembangkan dengan baik. Selain itu, kepercayaan antara pemangku kepentingan menjadi kunci dalam pemberdayaan ekonomi berbasis Masjid.

Menurut Nurjamilah (2016) bahwa Pemberdayaan ekonomi yang dilakukan Rasulullah saw. pada waktu di Madinah sederhana. Pada saat itu, Nabi menyampaikan nashihat-nashihat etika bisnis, seperti larangan menipu, dan berbohong dalam jual beli di pasar, larangan mengurangi timbangan, jujur, serta haramnya riba, dan sebagainya. implikasinyapun pada waktu itu belum terlihat besar. Akan tetapi, dasar-dasar yang dimulai oleh Nabi dari masjid Nabawi pada periode sesudah Nabi, memiliki pengaruh yang luar biasa pada perekonomian Islam

Penguatan dan pemberdayaan ekonomi umat di masjid diperlukan strategi yang pas. Menurut Falah (2017) bahwa Strategi dalam pemberdayaan umat yang perlu diperhatikan 1. Peningkatan kemampuan menuju kemandirian sosial dan ekonomi.

2. Pendampingan sosial melalui lembagalembaga manajemen dan ekonomi yang ada di lingkungannya.

3. Pembangunan dan pengembangan sistem informasi penanganan fakir miskin dan

4. Inisiasi dan pengembangan jaringan kerja penanganan. 
Menurut Farida (2014) bahwa masjid harus difungsikan bukan hanya sebatas pusat kegiatan ibadah bagi para jamaahnya, tetapi diharapkan dapat menjadi pusat aktiftas sosial dan ekonomi dan keilmuan bagi para jamaahnya. Penelitian yang dilakukannya menemukan bahwa dalam hal pemberdayaan masyarakat, setiap masjid memiliki standar untuk mengukur efektivitas pemberdayaan yang dikembangkannya. Sebagai contoh pada Masjid Salman ukurannya adalah pada perubahan mindset cara pandang dan paradigma sasaran penerima pemberdayaan. Pada akhirnya pemberdayaan model ini akan menghasilkan ilmuan dan teknokrat yang tidak mengekploitasi alam seperti pada sains dan teknologi yang sekuler, tetapi mereka akan menjadi teknokrat yang mempertimbangkan fungsi khalifah fil- ardhi sebagai pemelihara alam semesta.

Fadlullah dan Amir (2017) berkesimpulan dalam penelitiannya bahwa pemberdayaan masyarakat jamaah masjid telah menunjukkan hasil berupa program peningkatan perekonomian dalam bentuk pelatihan dan pendirian koperasi. Selanjutnya, ditemukan bahwa penghambat dalam pemberdayaan jamaah masjid melalui koperasi adalah terbatasnya modal. Hal yang positif temuan penelitian ini adalah bahwa pemberdayaan jamaah masjid Nurul Hidayah sudah mampu menggali, mendorong dan memotivasi serta menjadikan jamaah prasejahtera lebih mandiri dan percaya diri.
Perekonomian menurut Smith dalam Rahardja dan Mandala (2010), bahwa perekonomian sebagai sebuah system seperti halnya alam semesta. Sebagai system maka perekonomian mempunyai kemampuan untuk penstabilan otomatis untuk menjaga keseimbangannya. Jadi dalam ekonomi akan mengarah ke titik keseimbangan. Aktivitas ekonomi dimanapun akan menuju ke arah keseimbangan dengan instrument permintaan dan penawaran. Jika ada permintaan suatu barang atau jasa maka mendorong munculnya penawaran barang dan jasa yang diminta. Hal ini juga akan terjadi di lingkungan masjid. Untuk itu perlu diidentifikasi permintaan barang dan jasa apa yang ada di lingkungan masjid.

Menurut Murdani, Widayani, dan Hadromi (2019) bahwa sektor Usaha Mikro Kecil dan Menengah (UMKM) memiliki peran penting dalam mendorong pertumbuhan perekonomian Indonesia. Hampir sekitar $87 \%$ kontribusi usaha mikro kecil kedalam perekonomian Indonesia dam memiliki andil sebesar $85 \%$ dalam penyerapan tenaga kerja. Berdasarkan hasil penelitian Murdani, Widayani dan Hadromi (2019) bahwa dalam pengembangan ekonomi untuk masyarakat perlu dilakukan dengan metode pendampingan sosial terutama dalam membantu memecahkan persoalan yang sedang dihadapi. Namun dalam pengembangan ekonomi mikro dan kecil biasanya terhambat oleh keterbatasan modal, 
sarana dan prasarana serta partisipasi masyarakat yang rendah.

Sejalan dengan Murdani, Widayani dan Hadromi (2019) permasalahan yang dihadapi Usaha Mikro Kecil Menengah sangat beragam. Menurut hasil kajiannya bahwa permasalahan utama dalam pemberdayaan ekonomi mikro kecil adalah sumber daya manusia, kelembagaan, dan pemasaran. Ini artinya bahwa dalam pengembangan usaha mikro kecil permasalahan tersebut harus dipecahkan terlebih dahulu.

Hasil penelitian Erziaty (2015) bahwa pemberdayaan ekonomi masjid dapat dilakukan melalui penguatan sumberdaya manusia kepengurusan organisasi masjid, pemanfaatan aset infrastruktur, optimalisasi dana Zakat Infak dan Sadakah (ZIS) umat dan remaja masjid. Hal yang penting lagi adalah pembentukan lembaga pemberdayaan ekonomi umat seperti baitul maal masjid yang mampu mengumpulkan dana ZIS dari donatur dan menyalurkanya untuk kegiatan ekonomi produktif umat khususnya pemberian modal usaha fakir miskin.

Dari sisi lain, pengembangan usaha untuk pembinaan umat diperlukan dana yang tidak sedikit. Dalam hal ini modal dapat diperoleh dari zakat infaq shadaqah. Hal ini seperti pendapat Kasdi (2016) bahwa di tengah problem sosial masyarakat dan tuntutan kesejahteraan ekonomi, eksistensi Zakat Infaq Shadaqah dan Waqaf (ZISWAF) menjadi penting. Alasanya adalah bahwa
ZISWAF selain berdimensi spiritual, juga berdimensi kesejahteraan ekonomi. Ini merupakan pilar penyangga bagi tegaknya institusi-institusi social keagamaan masyarakat muslim selama berabad-abad. Hal itu dilakukan melalui penyediaan dana dan sarana pendukung bagi kegiatan-kegiatan ritual keagamaan, pendidikan, pengembangan ilmu pengetahuan, seni dan budaya. ZISWAF juga dapat bermanafaat untuk meningkatkan taraf hidup masyarakat di bidang ekonomi, terutama sekali jika wakaf dikelola dengan manajemen yang rapi, teratur dan profesional.

Berkaitan dengan pemanfaatan zakat infaq shadaqah dan waqaf untuk pemberdayaan umat aspek transparansi dan akuntabilitas juga harus diperhatikan. Menurut Ismatullah dan Tina (2018) trasparansi dan akuntabilitas merupakan hal yang sangat penting dan strategis dalam mempertanggung jawabkan segala aktivitas yang berhubungan dengan penghimpunan dan penyaluran dana termasuk dalam pengelolaan dana masjid. Sejalan dengan hal ini maka diperlukan aktivitas pengawasan secara komprehensif dari tahap perencanaan sampai dengan evaluasi.

Dengan mendasarkan uraian di atas, agar maksud kajian lebih jelas dan terarah maka disusun tujuan kajian dengan sistematis. Adapaun tujuan dari kajian ini adalah:

a. mengidentifikasi potensi ekonomi Masjid Nurul Iman 
b. menganalisis potensi ekonomi Masjid Nurul Iman dalamm perekonomian

c. menyusun strategi dalam pengembangan ekonomi masjid

Diharapkan dari kajian ini bahwa pengembangan aspek ekonomi masjid dapat lebih efektif, efisisen dan sustainable. Dengan demikian maka pengurus masjid dapat lebih kreatif dan inovatif sehingga pengelolaan masjid lebih professional dan usaha memakmurkan masjid dapat terwujud.

\section{METODE PENELITIAN}

Secara teori bahwa metode penelitian kualitatif adalah metode penelitian yang berlandaskan pada filsafat postpositivisme (Sugiyono,2011). Pendekatan ini digunakana untuk meneliti pada kondisi obyek yang alamiah. Artinya bahwa obyek yang diteliti didekati secara apa adanya tidak ada perlakuan khusus jadi benar-benar natural. Oleh karena itu maka posisi peneliti menjadi instrument kunci. Kualitas hasil dari kajian ini sangat tergantung dari kualitas peneliti.

Dalam hal ini kajian dilakukan secara pendekatn kualitatif deskriptif. Dalam kajian ini data diperoleh dari wawancara langusng dengan para pemangku kepentingan. Selain itu juga dilakukan secara purposive dengan pendekatan Forum Group Discussion (FGD). Kegiatan ini dimaksudkan agar data dapat diperoleh lebih berkualitas. Selain itu, dengan pendekatan ini data akan lebih spesifik dan seusai dengan inti kajian. Alasannya adalah dengan FGD informasi tentang permasalahan akan bersifat lokal dan spesifik. Sedangkan data sekunder diperoleh dari dokumentasi masjid dan beberapa sumber yang akuntabelitasnya dapat dipertanggungjawabkan. Data yang telah tersusun diseleksi dan dikelompokan sesuai dengan tujuan analisis.

Dengan data yang demikian maka diharapkan kajian akan lebih berkualitas dan sesuai dengan tujuan kajian. Selanjutnya untuk analisis digunakan pendekatan USG atau Urgency Seriousness Growth. Untuk analisis digunakan pendekatan SWOT.

\section{Pendekatan Analisis USG}

Metode USG (Urgency, Seriousness, and Growth) merupakan salah satu metode yang digunakan untuk menetapkan prioritas strategi yang akan dikembangkan. Urutan prioritas ini digunakan dengan pendekatn angka, dalam hal ini adalah angka 1 sampai dengan 5.

a. Urgency mempunyai pengertian bahwa isu ini didekati dengan prinisp keterdesakan. Semakin isu ini mendesak maka diberi angka relative tinggi. Jadi isu ini harus dibahas dikaitkan dengan waktu yang tersedia serta seberapa keras tekanan waktu tersebut untuk memecahkan masalah yang menyebabkan isu tadi. Dalam hal ini urgensi, dilihat dari tersedianya waktu, mendesak atau tidak masalah tersebut diselesaikan. Jadi 
uregensi dilihat dari tersedianya waktu, mendesak atau tidak masalah tersebut diselesaikan. Dengan kata lain bahwa urgency berkaitan dengan mendesaknya waktu yang dibutuhkan dalam menyelesaikan suatu masalah. Semakin tinggi urgensi suatu masalah artinya masalah tersebut harus segera diselesaikan.

b. Seriousness adalah pendekatan isu dilihat dari pendekatan yang dikaitkan dengan akibat yang timbul jika terjadi penundaan pemecahan masalah. Ini artinya bahwa kalau masalah penyebab isu tidak dipecahkan maslaha menjai lebih serius. Dengan kata lain bawha seriousness atau tingkat keseriusan dilihat dari dampak masalah tersebut terhadap produktifitas kerja atau tingkat keberhasilan. Jadi seriousness atau tingkat keseriusan dari masalah, yakni dengan melihat dampak masalah tersebut terhadap produktifitas kerja, pengaruh terhadap keberhasilan, membahayakan system atau tidak. Dengan kata lain bahwa seriousness berkaitan dengan besarnya dampak yang ditimbulkan oleh suatu masalah terhadap suatu organisasi. Dampak tersebut salah satunya dapat menimbulkan penurunan produktivitas maupun dampak terhadap keselamatan, sumberdaya, serta sumber dana dari suatu organisasi. Sehingga semakin tinggi dampak yang ditimbulkan maka semakin serius masalah yang terjadi.

c. Growth yang dimaksud dalam hal ini adalah bahwa kejadian dilihat sampai seberapa tinggi dan besar suatu kejadian menjadi berkembang ha linin dikaitkan kemungkinan masalah penyebab isu. Pengertiaannya adalah bahwa apabila isu ini tidak diselesaikan maka kegiatan ini makin memburuk Dengan kata lain Growth berkaitan dengan pertumbuhan suatu masalah, dimana semakin cepat masalah tersebut berkembang maka semakin tinggi tingkat pertumbuhannya. Fenomena yang cepat berkembang mengindikasi prioritas penyelesaiannya semakin tinggi. Penentuan masingmasing prioritas strategi dilakukan berdasarkan kriteria tertentu. Kriteria tersebut meliputi tingkat keterdesakan, serius, dan pertumbuhan suatu masalah.

\section{Pendekatan analisis SWOT}

Analisis SWOT adalah suatu analisis dengan menggunkan identifikasi berbagai factor secara sitematis untuk merumuskan strategi organisasi (Rangkuti 2001). Analisis ini berdasarkan logika yang dapat memaksimalkan kekuatan dan peluang namun secara bersamaan dapat meminimalkan kelemahan dan ancaman.

\section{a. Kekuatan (Strength)}


Pada dasarnya kekuatan adalah factor yang dimiliki oleh perusahaan. Pada langkah operasional dilakukan analisis tentang kelebihan yang dimiliki perusahaan. Kelebihan ini meliputi berbagai aspek seperti teknologi, kualitas hasil produksi, lokasi strategis, atau unsur kekuatan lainnya yang lebih menekankan pada keunggulan perusahaan.

\section{b. Kelemahan (Weakness)}

Kelemahan adalah factor yang secara intrinsic dimiliki oleh organisasi dalam pencapaian tujuan. Dalam hal identifikasi kelemahan suatu organisasi dapat melakukan langkah komparasi dengan pesaing. Dalam hal ini factor apa yang dimiliki organisasi namun tidak dimiliki organisasi. Daftar kelemahan disusun secara lebih obyektif bisa dengan testimoni komponen yang dilayani yang umumnya lebih mengetahui apa yang kurang dari organisasi.

\section{c. Peluang (Opportunity)}

Secara konsep bahwa peluang adalah kesempatan yang dimiliki oleh organisasi. Faktor ini pada umumnya ditemukan pada awal membangun bisnis. Ini karena bisnis dibentuk berdasarkan peluang atau kesempatan untuk menghasilkan keuntungan. Unsur peluang termasuk daftar apa saja yang memungkinkan bisnis mampu bertahan dan diterima di masyarakat, baik dalam jangka pendek maupun jangka panjang.

\section{d. Ancaman (Threats)}

Secara prinsip bahwa ancaman adalah sesuatu yang datang dari luar dan diperkirakan akan menjadi penghalang laju orgnaisasi pada saat organisasi akanmencpai tujuannya. Analisis terhadap unsur ancaman sangat penting karena menentukan apakah bisnis dapat bertahan.

Berikut merupakan gambaran diagram kartesius: Opportunities Weaknesses Strengths dan) Threats.

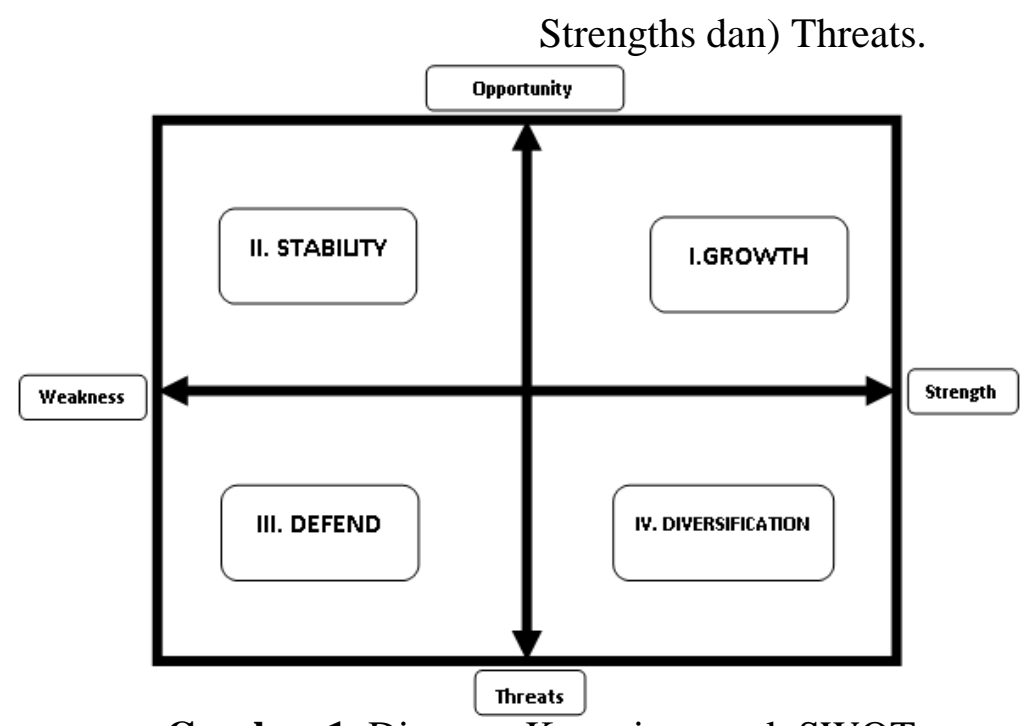

Gambar 1. Diagram Kartesius untuk SWOT 
AL-URBAN: Jurnal Ekonomi Syariah dan Filantropi Islam

Vol. 3, No. 2, Desember 2019

http://journal.uhamka.ac.id/index.php/al-urban

p-ISSN: 2580-3360 e-ISSN: 2581-2874

DOI: 10.22236/alurban_vol3/is2pp203-226

Hal 203-226

Gambar di atas merupakan diagram Kartesius. Diagram ini merupakan cara menentukan kuadran yang tepat. Untuk itu maka perlu dihitung selisih dari subtotal faktor strengths dengan weaknesses (titik pertama) dan selisih dari subtotal faktor opportunities dengan threats (titik kedua).

Menurut Anggraeni, Sunarti dan Mawardi (2017) bahwa Kuadran I: Merupakan situasi yang sangat menguntungkan. Perusahaan tersebut memiliki peluang dan kekuatan sehingga dapat memanfaatkan peluang yang ada. Strategi yang harus diterapkan dalam kondisi ini adalah mendukung kebijakan pertumbuhan yang agresif. (Growth oriented strategy).

Kuadran II: Meskipun menghadapi berbagai ancaman, perusahaan ini masih memiliki kekuatan dari segi internal. Strategi yang harus diterapkan adalah menggunakan kekuatan untuk memanfaatkan peluang jangka panjang dengan cara strategi diversifikasi (produk/jasa).

Kuadran III: Perusahaan menghadapi peluang pasar yang sangat besar, tetapi dilain pihak, ia menghadapi beberapa kendala/kelemahan internal. Fokus perusahaan ini adalah meminimalkan masalah-masalah internal perusahaan sehingga dapat merebut peluang pasar yang lebih baik.

Kuadran IV: Ini merupakan situasi yang sangat tidak menguntungkan, perusahaan tersebut menghadapi berbagai ancaman dan kelemahan

\section{Pendekatan EFAS dan IFAS}

Langkah selanjutnya adalah dengan menggunakan table EFAS dan IFAS. Tabel EFAS Tabel EFAS terdiri dari lima kolom. Untuk menyusun tabel EFAS, terlebih dahulu dilakukan identifikasi lingkungan eksternal, baik dari faktor peluang maupun ancaman.

Dalam penyusunan tabel ini disusun dengan bobot. Dalam hal ini didekatai dengan pendekatan USG. Yang masih masingmasing unsur diberi nilai dari 1,0 (tidak penting) sampai dengan 5,0 (sangat penting/most important). Semakin tinggi nilai ini, maka hal tersebut mengartikan faktor tersebut sangat berpengaruh terhadap keberlangsungan organisasi.

Dari Total nilai ini selanjutnya dihitung bobot. Bobot ini dihitung dengan membandingkan antara jumlah angka Unsur USG dengan grand totalnya. Selanjutnya disusun rating (peringkat) pada setiap factor. Caranya menurut Rangkuty (2001) adalah dengan memberikan angka peringkat 4,0 (sangat baik/outstanding) sampai 1,0 (buruk/poor). Selanjutnya untuk kolom komentar diuraikan argument tentang isu penting mengapa faktor-tersetbu diprioritaskan. 
Selanjutnya dilakukan pengambaran grafik kartesius untuk menentukan kuadaran dari organisasi yang kita susun. Cara menentukan kuadran yang tepat, maka perlu dihitung selisih dari subtotal faktor strengths dengan weaknesses (titik pertama) dan selisih dari subtotal faktor opportunities dengan threats (titik kedua). Jika hasil selisih dari subtotal faktor strengths dengan weaknesses adalah positif (+), maka titik pertama akan berada di sisi garis horizontal sebelah kanan titik 0. Jika hasilnya negatif (-), maka titik pertama akan berada di sisi garis horizontal sebelah kiri titik 0. Jika hasil selisih dari subtotal faktor opportunities dan threats adalah positif (+), maka titik kedua akan berada di sisi garis vertikal di bawah 0 . Akhirnya akan ada dua titik yang nantinya akan menentukan kuadran.

Dari hasil perhitungan operasional tersebut akan diperoleh kuadran atau posisi dari organisasi. Letak posisi ini akan menentukan strategi pengembangan organisasi. Oleh karena itu, kemudian dilakukan analisis dan penyusunan strategi untuk memperoleh tujuan yang telah dirumuskan dengan baik dan tepadu.

\section{HASIL DAN PEMBAHASAN}

\section{A. Profil Masjid Nurul Iman, Ahlul Jannah}

Masjid Nurul Iman merupakan salah satu unit kegiatan Yayasan Ahlul Jannah. Selain Masjid, Yayasan Ahlul Jannah mempunyai unit kegiatan lain, yaitu unit penyelenggaraan
Pendidikan Anak Usia Dini (PAUD) dan unit penyelenggaraan Pendidikan TPA.

Masjid Nurul Iman beralamat di Jalan Antene IV No. 4 Radio Dalam, Kelurahan Gandaria Utara, Kecamatan Kebayoran Baru, Kota Jakarta Selatan. Masjid ini menempati area Komplek RRI Radio Dalam dan didirikan tahun 1996. Masjid ini menempati lahan seluas 600 meter persegi, sarana Pendidikan Anak Usia Dini (PAUD) dan sarana untuk Pendidikan Taman Pendidikan Al Quran (TPA) seluas kurang lebih 120 meter persegi.

Jamaah Masjid Nurul Iman kurang lebih sejumlah 100 jamaah setiap penyelenggaraan sholat wajib lima waktu sehari. Namun untuk Sholat Jumat, Masjid Nurul Iman dihadiri Jamaah kurang lebih sejumlah 500 jamaah. Pada umumnya, jamaah berasal dari lingkungan Kelurahan Gandaria Utara, sebagian dari Kelurahan Kebayoran Lama Selatan dan sebagian dari Kelurahan Kramat Pela.

Dari sisi keuangan, penyelenggaraan aktivitas Masjid Nurul Iman dan pelaksnaaan dalam aktivitasnya didanai dari berbagai sumber, yaitu kotak Jumatan, kotak Yatim Dhuafa, Kotak Sego Jumat, kotak Sarana dan Prasarana. Jumlah perolehan dana total kurang lebih setiap bulannya Rp.29.0000.000 per bulan. Untuk kegiatan yang sifatnya monumental, pengurus Masjid Nurul Iman membagikan proporsal sumbangan sesuai dengan kebutuhan dan proyek yang akan 
dilaksanakan. Dalam hal ini sumbangan donator jumlahnya sangat variatif dari sumbangan Rp. 100.000,- sampai dengan Rp 25.000.000,-

Lokasi Masjid Nurul Iman sangat strategis untuk kegiatan bisnis. Letak geogafis, kurang lebih 50 meter dari Jalan Raya Radio Dalam (Jalan Arteri). Lingkungan sekitar terbagi menjadi dua kelompok. Kelompok yang relative mantap dan kokoh dalam hal ekonomi dan sebagian relative masih kurang beruntung. Namun lokasi masjid sangat berdekatan dengan para pelaku usaha. Dari sisi penduduk, masyarakat sekitar juga mempunyai keyakinan yang relatif bervariasi.

Secara organic, susunan pengurus terdiri dari empat belas orang. Tiga orang pembina, enam orang pengawas dan enam orang pengurus. Sementara organ pendukung pengurus yang sehari-hari sebagai pelaksana kegiatan Masjid berjumlah 21 (dua puluh satu) orang yang terbagi menjadi tujuh divisi. Masing masing divisi terdiri dari tiga orang.

Kegiatan Masjid Nurul Iman sangat bervariatif. Kegiatan ini meliputi santunan anak yatim, kegiatan penyelenggaraan sego Jumat, penyelenggaraan Pendidikan Anak Usia Dini, Pengajian Remaja, Penyelenggaraan Sholat Wajib lima waktu, penyelenggaraan Sholat Jumat, Penyelenggaraan perayaan hari besar Islam seperti Idul Fitri dan Idul Adha. Selain itu dilaksanakan juga kegiatan Muslimah hari senin dan Jumat, Pembacaan Surat Yasin Setiap Malam Jumat, dan pelaksanaan kuliah Dhuha sekali seminggu.

Dari aspek usaha bisnis khususnya untuk usaha kaki lima, sekitar Masjid Nurul Iman juga telah banyak ditempati usaha kaki lima. Jumlah pedagang kaki lima yang mangkal di sekitar Masjid Nurul Iman kurang lebih ada enam pedagang kaki lima. Jumlah ini cenderung terus bertambah. Kondisi seperti ini menunjukkan bahwa potensi Masjid Nurul Iman layak untuk bisnis terutama untuk pengembangan ekonomi skala kecil dan mikro.

\section{B. Analisis Kajian USG dan SWOT}

Dalam pelaksanaan analisis dilakukan beberapa tahapan. Kajian ini menggunakan pendekatan kualitatif-deskriptif dengan menggunakan metode USG dan SWOT. Untuk operasionalnya menggunakan matrik IFAS dan EFAS. Agar sistematis berikut diuraikan tahapan operasional penyusunan aktivitas dalam kajian ini. Secara rinci terurai pendekatan tersebut adalah sebagai berikut.

1. Identifikasi factor factor SWOT yang meliputi factor kekuatan, kelemahan, peluang dan ancaman.

2. Penilaian dengan mengguna pendekatan USG. Masing masing factor dinilai dan dikuantifikasi dengan skala likert 1,0 (kurang prioritas) sampai dengan 5,0 (paling prioritas). Dalam hal ini data diperoleh dengan diskusi para pemangku kepentingan yang mumpuni. Nilai faktor- 
faktor SWOT yang ada pada USG dijumlahkan dan kemudian dari masing kelompok, yaitu kekuatan, kelemahan, peluang dan ancaman dilakukan pembobotan.

3. Bobot tersebut dijadikan dasar untuk menyusun matrik IFAS dan EFAS.

4. Selanjutnya pada Matrik EFAS dan IFAS dilakukan pemeringkatan. Pemeringkatan dengan nilai 1,0 (kurang penting) sampai dengan 4,0 (paling penting). Ini mendasarkan pada pendapat Rangkuti (2001).

5. Penyusunan diagram kartesius untuk skor yang ada pada SWOT dengan cara mengurangkan total nilai kekuatan dengan total nilai kelemahan. Berlaku sama untuk faktor peluang dan ancaman. Dengan dasar ini dilakukan penggambaran diagram kartesius.

6. Penyusunan matrik SWOT dengan menggabungkan dengan tetap memperhatikan faktor-faktor yang ada pada SWOT.

Secara rinci operasional teknis pelaksanaan kajian penyusunan strategi pengembangan ekonomi di Masjid Nurul Iman adalah sebagai berikut.

1. Identifikasi factor kekuatan, kelemahan pelaung dan ancaman.

\section{Faktor Kekuatan}

a. Bertambahnya jumlah jaamh

b. Strategisnya letah geogafis

c. Kejujuran pengurus
d. Berbadan hukuma
e. Kepercayaan masyarakat

Faktor Kelemahan
a. Persatn pengurus
b. sedikuitnya inisiaator
c. lemahnya modal keraj
d. kureng telatennyaa unutk berbsinis
e. kehandalan binsinis modek.

Faktor Peluang

a. Daya Beli masyarakat

b. Tingkat kepercaayaan masyasrakat

c. Dukungan pemeirntah

d. Dukungan odnatur tinggi

e. Jumlah asset tinggi

Faktor Ancaman
a. Saingan Bisnis
b. Pertentangan Fiqih
c. Moral Hazard Pengurus
d. Tata Kelola Binis di Masjid
e. Konflik Pengurus

2. Penilaian dengan menggunakan metode USG

Menurut Ismowaty (2014) bahwa Urgency, Seriousness, Growth (USG) merupakan tool yang digunakan untuk menentukan urutan prioritas isu dengan menentukan tingkat urgensi, keseriusan, dan perkembangan isu dengan menentukan skala nilai 1 - 5 atau 1 - 10. Dalam hal penggunaan metode USG, secara teknis dilakukan dengan mengukur masing masing faktor dinilai dengan menggunakan skala 1,0 sampai 5,0 sebagaimana telah diuraikan di atas. 
Kemudian angka untuk masing-masing faktor dijumlahkan. Semakin tinggi total skor-nya maka jumlahnya semakin tinggi. Jadi Isu yang memiliki total skor tertinggi merupakan isu prioritas. Adapun hasilnya adalah sebagai berikut:

Tabel 1. Analisis USG Faktor Kekuatan dan Kelemahan

\begin{tabular}{|c|c|c|c|c|c|c|}
\hline No & Urutan & KATEGORI & $\mathrm{U}$ & S & G & Total \\
\hline \multirow[t]{6}{*}{1} & Strength & & & & & \\
\hline & A & Bertambahnya Jumlah Jamaah & 4 & 5 & 5 & 14 \\
\hline & $\mathrm{B}$ & Strategisnya Letak Geografis & 5 & 5 & 3 & 13 \\
\hline & $\mathrm{C}$ & Kejujuran Pengurus & 5 & 4 & 4 & 13 \\
\hline & $\mathrm{D}$ & Berbadan Hukum jelas & 4 & 5 & 4 & 13 \\
\hline & E & kepercayaan masyarakat & 5 & 5 & 3 & 13 \\
\hline \multirow[t]{7}{*}{2} & \multicolumn{6}{|c|}{ Weakness } \\
\hline & A & Persatuan Pengurus & 5 & 3 & 3 & 11 \\
\hline & B & Sedikitnya inisiator & 4 & 5 & 5 & 14 \\
\hline & $\mathrm{C}$ & Lemahnya modal kerja & 3 & 3 & 4 & 10 \\
\hline & $\mathrm{D}$ & Kurang telaten untuk berbisn is & 3 & 5 & 5 & 13 \\
\hline & $\mathrm{E}$ & Bisnis Mode1 Handal & 5 & 3 & 5 & 13 \\
\hline & & & & & & 127 \\
\hline
\end{tabular}

Sumber: Data diolah, 2019

Berdasarkan analisis USG maka faktor jumlah jamaah merupakan faktor yang sangat dominan dalam pencapaian tujuan pengembangan ekonomi masjid. Selanjutnya faktor tidak adanya insiator dalam memulai aktivitas pengembangan perekonomian masjid merupakan faktor yang paling dominan. Selanjutnya dengan cara yang sama dilakukan untuk identifikasi peluang dan ancaman. Selanjutnya dilakukan dengan perlakuan yang sama. Secara teknis dalam hal ini diukur masing masing faktor dengan menggunakan skala 1,0 ssampai 5,0. Adapun hasilnya untuk nilai USG faktor peluang dan ancaman adalah sebagai berikut: 
Tabel.2. Analisis USG Faktor Peluang dan Ancaman

\begin{tabular}{|r|l|l|r|r|r|r|}
\hline No & Urutan & KATEGORI & U & S & G & Total \\
\hline 3 & Opportunity & & & & \\
\hline & A & $\begin{array}{l}\text { Daya Beli masyarakat } \\
\text { setempat }\end{array}$ & 5 & 3 & 4 & 12 \\
\hline & B & $\begin{array}{l}\text { Tingkat Kepercayaan } \\
\text { Masyarakat }\end{array}$ & 3 & 4 & 5 & 12 \\
\hline & C & Dukungan Pemerintah & 5 & 4 & 5 & 14 \\
\hline & D & Dukungan Donatur Tinggi & 3 & 3 & 5 & 11 \\
\hline & & $\begin{array}{l}\text { Jumlah Aset Tetap yang } \\
\text { bernilai }\end{array}$ & 5 & 5 & 3 & 13 \\
\hline & E & & & & & \\
\hline 4 & Threatens & & 4 & 4 & 4 & 12 \\
\hline & A & Saingan Bisnis & 2 & 5 & 5 & 12 \\
\hline & B & Pertentangan Fiqih & 5 & 4 & 5 & 14 \\
\hline & C & Moral Hazard Pengurus & 4 & 5 & 4 & 13 \\
\hline & D & Tata Kelola Binis di Masjid & 3 & 4 & 5 & 12 \\
\hline & E & Konflik Pengurus & & & & \\
\hline & & & & & & \\
\hline
\end{tabular}

Dalam hal ini faktor ancaman terbesar untuk pengembangan ekonomi masjid adalah moral hazard pengurus. Hal ini mungkin lebih disebabkan karena ketidaktahuannya atau kurangnya pemahaman pentingnya faktor ekonomi dalam pengembangan ekonomi masjid. Sedangkan faktor peluang yang dominan adalah faktor dukungan pemerintah dalam pengembangan ekonomi masjid.

\section{Penyusunan Matrik Faktor Strategi}

\section{Internal IFAS}

Selanjutnya menurut Rangkuti (2001) bahwa setelah factor-faktor strategis internal suatu organisasi diidentifikasi maka dapat disusun tabel IFAS (Internal Factors Analysis Summary) disusun untuk merumuskan factor-faktor strategi internal tersebut dalam kerangka kekuatan (strength) dan kelemahan (weakness). Adapun ringkasannya dapat dilihat pada Tabel 3.

Sejalan dengan penyusunan Tabel IFAS, pada penyusunan table EFAS dilakukan dengan cara yang sama. Adapun Tabel EFAS ditampilkan pada Tabel 4. 
Tabel 3. Matrik Internal Factor Analysis Strategi (IFAS).

\begin{tabular}{|c|c|c|c|c|c|c|}
\hline No & Urutan & KATEGORI & BOBOT & RATING & SKORE & KOMENTAR \\
\hline \multirow[t]{6}{*}{1} & Strength & & & & & \\
\hline & $\mathrm{a}$ & $\begin{array}{l}\text { Bertambahnya Jumlah } \\
\text { Jamaah }\end{array}$ & 0,21 & 4 & 0,85 & \multirow{5}{*}{$\begin{array}{l}\text { Tingkatkan pel } \\
\text { jamaah } \\
\text { Aksesibilitas tiı } \\
\text { aktivitas Bisnis } \\
\text { Kotak Amal sh } \\
\text { bertambah }\end{array}$} \\
\hline & $\mathrm{b}$ & Strategisnya Letak Geografis & 0,20 & 3 & 0,59 & \\
\hline & $\mathrm{c}$ & Kejujuran Pengurus & 0,20 & 3 & 0,59 & \\
\hline & $\mathrm{d}$ & Berbadan Hukum jelas & 0,20 & 4 & 0,79 & \\
\hline & $\mathrm{e}$ & kepercayaan masyarakat & 0,20 & 3 & 0,59 & \\
\hline \multirow[t]{7}{*}{2} & Weakness & & 1,00 & & 3,41 & \\
\hline & $\mathrm{a}$ & Persatuan Pengurus & 0,18 & 2 & 0,36 & \multirow{5}{*}{$\begin{array}{l}\text { Munculnya kor } \\
\text { internal } \\
\text { Potensi bisnis } \\
\text { tidak optimal } \\
\text { Kinerja kurang }\end{array}$} \\
\hline & $\mathrm{b}$ & Sedikitnya inisiator & 0,23 & 3 & 0,69 & \\
\hline & $\mathrm{c}$ & Lemahnya modal kerja & 0,16 & 2 & 0,33 & \\
\hline & $\mathrm{d}$ & $\begin{array}{l}\text { Kurang telaten untuk } \\
\text { berbisnis }\end{array}$ & 0,21 & 3 & 0,64 & \\
\hline & $\mathrm{e}$ & Bisnis Model Handal & 0,21 & 2 & 0,43 & \\
\hline & & & 1,00 & & 2,44 & \\
\hline
\end{tabular}

Sumber: Data diolah, 2019

Tabel 4. Tabel Matrik Eksternal Factor Analysis Strategi (EFAS).

\begin{tabular}{|c|c|c|c|c|c|c|}
\hline No & URUTAN & KATEGORI & BOBOT & RATING & SKORE & $\overline{\mathrm{KOMENT}}$ \\
\hline 3 & Opportunity & & & & & \\
\hline & $\mathrm{a}$ & $\begin{array}{l}\text { Daya Beli masyarakat } \\
\text { setempat }\end{array}$ & 0,20 & 4 & 0,79 & \multirow{5}{*}{$\begin{array}{l}\text { Kemapanar } \\
\text { ekonomi } \\
\text { Jumlah p } \\
\text { kotak } \\
\text { bertambah } \\
\text { Intensitas } \\
\text { kehadiran } \mathrm{f} \\
\text { Luas } \\
\text { mencukupi } \\
\end{array}$} \\
\hline & $\mathrm{b}$ & $\begin{array}{l}\text { Tingkat Kepercayaan } \\
\text { Masyarakat }\end{array}$ & 0,20 & 3 & 0,59 & \\
\hline & $\mathrm{c}$ & Dukungan Pemerintah & 0,21 & 3 & 0,64 & \\
\hline & $\mathrm{d}$ & $\begin{array}{l}\text { Dukungan Donatur } \\
\text { Tinggi }\end{array}$ & 0,18 & 4 & 0,72 & \\
\hline & $\mathrm{e}$ & $\begin{array}{l}\text { Jumlah Aset Tetap yang } \\
\text { bernilai }\end{array}$ & 0,21 & 3 & 0,64 & \\
\hline & & & 1,00 & & 3,38 & \\
\hline \multirow[t]{7}{*}{4} & Threatens & & & & & \\
\hline & $\mathrm{a}$ & Saingan Bisnis & 0,21 & 3 & 0,63 & \multirow{5}{*}{$\begin{array}{l}\text { Peningkatal } \\
\text { Kompetisi } \\
\text { Mitigasi res } \\
\text { Laporan bis } \\
\text { kurang tert }\end{array}$} \\
\hline & $\mathrm{b}$ & Pertentangan Fiqih & 0,21 & 3 & 0,63 & \\
\hline & $\mathrm{c}$ & Moral Hazard Pengurus & 0,21 & 2 & 0,42 & \\
\hline & $\mathrm{d}$ & $\begin{array}{l}\text { Tata Kelola Bsinis di } \\
\text { Masjid }\end{array}$ & 0,18 & 3 & 0,53 & \\
\hline & $\mathrm{e}$ & Konflik Pengurus & 0,19 & 2 & 0,39 & \\
\hline & & & 1,00 & & 2,60 & \\
\hline
\end{tabular}

Sumber: Data diolah, 2019

Selanjutnya untuk memudahkan memudahkan dalam penggambaran diagram penyusunan grand strategy pengembangan kartesius SWOT. Secara rinci matriks ekonomi masjid dilakukan penyusunan Penggabungan IFAS dan EFAS adalah matrik penggabungan antara IFAS dan sebagai berikut.

EFAS. Aktivitas ini dilakukan untuk 
Tabel 5. Matriks Penggabungan IFAS + EFAS

\begin{tabular}{|l|l|l|}
\hline Sub Total & Sub Total & 0,97 \\
Strength & Weakness & \\
\hline Sub Total & Sub Total & 0,78 \\
Opportunity & Threat & \\
$=\mathbf{3 , 3 8}$ & $=2,60$ & \\
\hline $\begin{array}{l}\text { Sub Total S } \\
+ \text { O }\end{array}$ & Sub Total & \\
$=6,79$ & $\mathrm{~W}+\mathrm{T}$ & \\
\hline
\end{tabular}

Sumber: data diolah 2019

Untuk menentukan strategy masjid dalam terinci diagram kartesius strategi pengembangan ekonomi digunakan hasil pengembangan ekonomi di Masjid Nurul penggabungan nilai IFAS dan EFAS. Dengan Iman adalah sebagai berkut:

dasar ini dibuat diagram kartesius. Secara

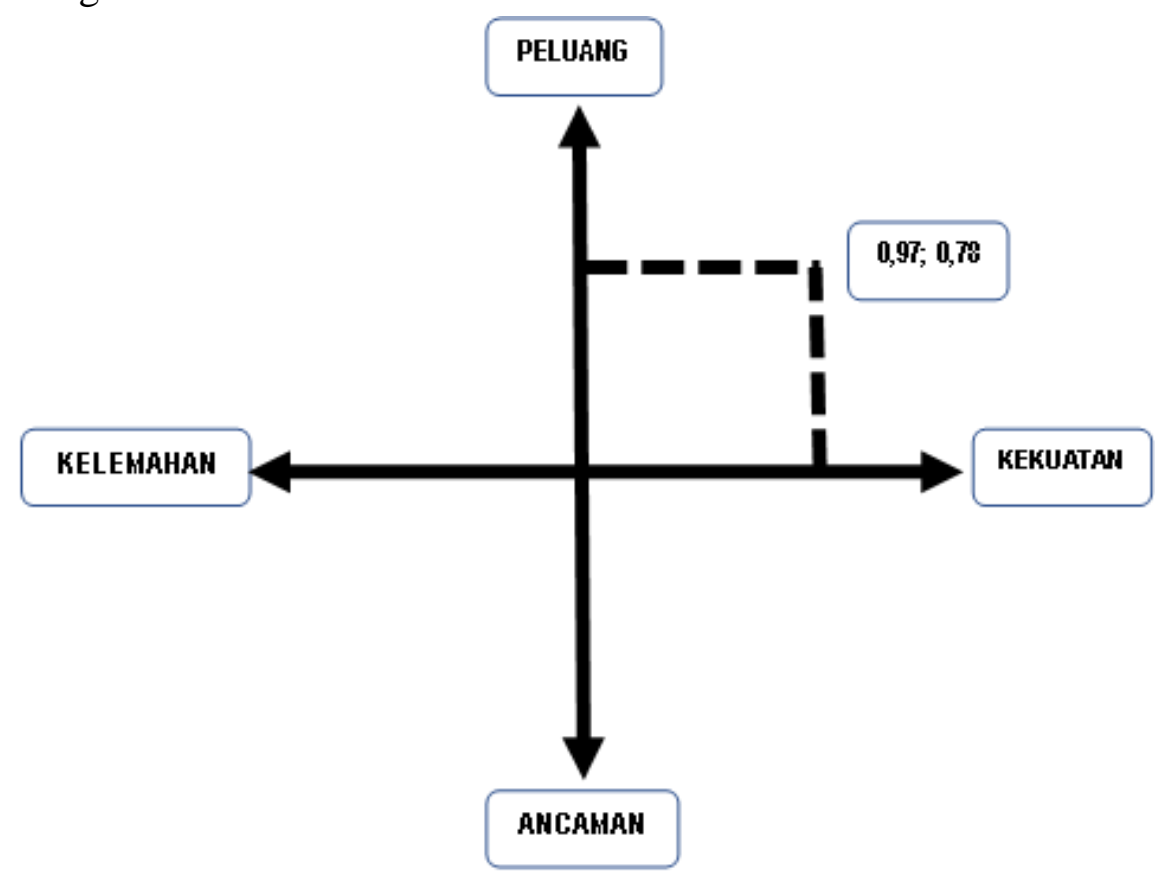

Gambar 2. Diagram Kartesius Pengembangan Masjid Nurul Iman

Berdasarkan perhitungan ditemukan pengembangan ekonomi yang perlu bahwa nilai total IFAS adalah 0,97 dan nilai mendapat perhatian adalah berada pada total EFAS adalah 0,78. Kemudian Kuadran I. Ini mempunyai pengertian bahwa dinyatakan oleh Anggraeni, Sunarti dan situasi yang sangat menguntungkan. Pada Mawardi (2017) bahwa strategy masjid dalam strategy ini berarti masjid memiliki peluang 
dan sekaligus kekuatan untuk dapat mewujudkan tujuan pengembangan ekonomi masjid.

Berdasarkan diagram kartesius diperoleh strategy dalam pengembangan ekonomi Masjid Nurul Iman. Selanjutnya maka perlu diperhatiakan arah kebijakan, program dan kegiatan agar strategy tersebut dapat lebih operasional. Berkaitan dengan hal ini maka berikut disusun matriks SWOT untuk menjadikan strategy tersebut lebih operasional. Berikut matriks SWOT dalam pengembangan ekonomi Masjid Nurul Iman

Tabel 6. Matriks SWOT Pengembangan Masjid Nurul Iman

\begin{tabular}{|c|c|c|}
\hline & Strength & Weakness \\
\hline EFAS & $\begin{array}{l}\text { 1. Bertambahnya } \\
\text { jumlah jamaah } \\
\text { 2. Strategisnya letak } \\
\text { geogafis } \\
\text { 3. Kejujuran pengurus } \\
\text { 4. Berbadan hukum } \\
\text { 5. Kepercayaan } \\
\text { masyarakat }\end{array}$ & $\begin{array}{l}\text { 1.Persatuan pengurus } \\
\text { 2.Sedikuitnya inisiator } \\
\text { 3.Lemahnya modal kerja } \\
\text { 4. Kurang telatennyaa } \\
\text { berbsinis } \\
\text { 5. Kehandalan Model Bisnis. }\end{array}$ \\
\hline $\begin{array}{l}\text { Opportunity } \\
\text { 1. Daya Beli masyarakat } \\
\text { 2. Tingkat kepercaayaan } \\
\text { masyarakat } \\
\text { 3. Dukungan Pemerintah } \\
\text { 4. Dukungan Donatur } \\
\text { tinggi } \\
\text { 5. Jumlah Asset tinggi }\end{array}$ & $\begin{array}{l}\text { Strategi S-O } \\
\text { 1. Pembentukan Unit } \\
\text { Bisnis Baru } \\
\text { 2. Peningkatan mutu } \\
\text { pelayanan bisnis } \\
\text { 3. Kapitalisasi modal } \\
\text { dari berbagai sumber } \\
\text { 4. Ekspansi bisnis yang } \\
\text { sudah berjalan }\end{array}$ & $\begin{array}{l}\text { Strategi W-O } \\
\text { 1. Pemanfaatan dukungan } \\
\text { pemerintah } \\
\text { 2. Pemanfaatan dukungan } \\
\text { donatur bisnis } \\
\text { 3. Permohonan CSR untuk } \\
\text { modal kerja }\end{array}$ \\
\hline $\begin{array}{l}\text { Threats } \\
\text { 1.Saingan Bisnis } \\
\text { 2. Pertentangan Fiqih } \\
\text { 3.Moral Hazard Pengurus } \\
\text { 4.Tata Kelola Bisnis di } \\
\text { Masjid } \\
\text { 5.Konflik Pengurus }\end{array}$ & $\begin{array}{l}\text { Strategi S-T } \\
\text { 1. Peningkatan Kerja } \\
\text { sama dengan Bisnis } \\
\text { Syariah } \\
\text { 2. Penguatan karakter } \\
\text { muslim pengurus } \\
\text { 3. Pengembangan SDM } \\
\text { untuk Bisnis }\end{array}$ & $\begin{array}{l}\text { Strategi W-T } \\
\text { 1. Menjajagi donator tanpa } \\
\text { ikatan } \\
\text { 2. Mendekati ahli bisnis yang } \\
\text { gratis 3. Mengikuti pelatihan } \\
\text { bisnis syariah }\end{array}$ \\
\hline
\end{tabular}

Sumber: data diolah 2019

Memperhatikan analisis USG diperoleh faktor-faktor yang dominan dalam setiap kelompok baik kekuatan dan kelemahan maupun kelompok peluang dan ancaman. Untuk kelompok kekuatan yang paling dominan adalah faktor banyaknya jumlah jamaah sedangkan untuk faktor kelemahan yang dominan adalah sedikitnya jumlah inisiator. Sementara dari kelompok eksternal maka kelompok peluang yang paling dominan adalah dukungan pemerintah sedangkan yang paling dominan untuk kelompok ancaman adalah Moral Hazard pengurus. Untuk itu perlu dilakukan internalisasi dengan baik agar faktor-faktor tersebut dikelola dengan baik dan strategy 
dalam mewujudkan tujuan pengembangan ekonomi Masjid Nurul Iman terwujud dengan baik.

Dengan mendasarkan pada diagram kartesius dan matrik SWOT serta faktor dominan dalam setiap kelompok maka strategi yang diperoleh dalam rangka pengembangan ekonomi Masjid Nurul Iman adalah strategi Strength dan Opportunity (Strategy S-O) dengan rincian sebagai berikut.

\section{Pembentukan Unit Bisnis Baru}

2. Peningkatan mutu pelayanan bisnis

3. Kapitalisasi modal dari berbagai sumber

4. Ekspansi bisnis yang sudah berjalan

Memperhatikan komponen dominan pada setiap komponen baik kekuatan dan kelemahan serta peluang dan ancaman serta strategi sebagaimana diuraikan di atas maka perlu disikapi dengan teliti dan cermat. Untuk itulah perlu disusun langkah operasional berupa kegiatan. Berdasarkan strategy tersebut dan mencermati sumber daya pengurus Masjid Nurul Iman, sumber daya keuangan, jumlah jamaah masjid, potensi lingkungan dan potensi ekonomi Masjid Nurul Iman maka disusun program pengembangan Ekonomi Masjid Nurul Iman. Program tersebut antara lain adalah sebagai berikut.

1. Identifikasi potensi bisnis yang cocok dengan lingkungan Masjid Nurul Iman

2. Pelatihan Sumber daya manusia pengurus Masjid Nurul Iman dengan fokus pada pengembangan bisnis

3. Pelatihan para pengurus yang bertugas dalam hal pengembangan bisnis tentang tata kelola usaha bisnis yang proper

4. Pembentukan unit bisnis Masjid Nurul Iman yang tepat dan sesuai dengan daya dukung

5. Peningkatan kerja sama dengan donator baik melalui CSR dan kerangka lain

6. Pemanfaatan Aset Masjid Nurul Iman secara proporsional dan professional dengan tetap berusaha mewujudkan tata kelola pengurusan bisnis yang sesuai ketentuan

Keenam program sangat sentral dalam usaha pengembangan ekonomi Masjid Nurul Iman. Program ini dapat dilakukan secara parallel namun yang perlu mendapat perhatian adalah bahwa waktu pelaksanaan sesegera mungkin. Ini penting karena dalam pengembangan bisnis dinamika perubahan sangat cepat dan tidak bisa dipolakan secara regular. Perkembangan bisnisnya sangat irregular. Selain itu yang cukup strategis adalah mitigasi resiko dari bisnis yang dilaksanakan. Dukungan jamaah dan kepercayaan jamaah jangan sampai hilang. Untuk itu inisiator bisnis kegiatan ekonomi masjid harus segera direalisasikan dengan tepat, efektif dan efisien.

Sebagai langkah awal adalah pendirian unit bisnis makanan ringan sehat dan halal yang skalanya Mikro atau Ultra Mikro sebagai percontohan. Dengan modal paling besar Rp.5.000.000,- rupiah. Tenaga kerja 
yang digunakan adalah jamaah masjid yang membutuhkan. Pasarnya dalam hal ini adalah juga jamaah Masjid Nurul Iman sebagai konsumen captive. Sementara konsumen lainnya masyarakat di sekitar masjid atau para jamaah masjid yang nomaden. Dengan usaha ini diharapkan akan terbentuk unit bisnis yang tangguh dan ulet. Dengan demikian maka usha bisnis bisa direplikasi untuk usaha lainnya.

Selain itu, pengurus Masjid Nurul Iman juga dapat implementasi dengan mendirikan baitul maal. Ini terbukti bahwa menurut Ramadhan, Idaul, dan Rahmad (2019) bahwa bentuk pemberdayaan ekonomi di Masjid dapat dibentuk Baitul Maal. Kajian mereka membuktikan bahwa Masjid Al -Ikhlas Malang pendirian Baitul maal telah memberikan peminjaman modal tanpa bunga. Aktivitas telah memberi peluang bagi pelaku usaha mikro kecil dapat melakukan usahanya dengan cepat dan memperoleh manfaat yang optimal. Dengan demikian baitul maal sangat membantu masyarakat untuk menjalankan usahanya.

\section{SIMPULAN}

Dari kajian dan hasil analisis tentang usaha pengembangan ekonomi Masjid Nurul Iman dengan pendekatan analisis USG, SWOT, EFAS dan IFAS maka diperoleh beberapa kesimpulan yang aggregative yakni Masjid dalam sejarah peradaban Islam merupakan sarana untuk melakukan dakwah dan pengembangan sumber daya ekonomi umat Islam. Untuk itu masjid disarankan agar umat membuat halaqah rutin di masjid untuk mendiskusikan tentang pengembangan ekonomi umat Islam. Masjid harus memberikan sinarnya, membimbing secara moral supaya dinamika ekonomi di pasar itu tumbuh berkembang untuk kemanusiaan.

Lokasi Masjid Nurul Iman sangat strategis untuk kegiatan bisnis. Letak geogafis, kurang lebih 50 meter dari Jalan Raya Radio Dalam (Jalan Arteri). Lingkungan sekitar terbagi menjadi dua kelompok. Kelompok yang relatif mantap dan kokoh dalam hal ekonomi dan sebagaian relatif masih kurang beruntung. Namun, Lokasi masjid sangat berdekatan dengan para pelaku usaha baik yang berskala besar dan berskala mikro dan kecil. Dengan demikian lingkungan Masjid Nurul Iman mempunyai potensi ekonomi yang tinggi.

Kelompok kekuatan yang paling dominan adalah factor benyaknya jumlah jamaah sedangkan unutk factor kelemahan yang dominan adalah sedikitnya jumlah inisiator. Sementara dari kelompok eksternal maka kelompok peluang yang paling dominan adalah dukungan pemerintah sedangkan yang paling dominan untuk kelompok ancaman adalah Moral Hazard pengurus. Hal ini perlu mendapat perhatian dalam usaha mewujudkan tujuan pengembangan ekonomi Masjid Nurul Iman terwujud.

Dengan analisis EFAS, IFAS dan 
diagram Kartesius diperoleh kesimpulan bahwa strategi besar dalam rangka pengembangan ekonomi Masjid Nurul Iman adalah strategi Strength dan Opportunity (Strategy S-O). Strategi ini meliputi pembentukan Unit Bisnis Baru, peningkatan mutu pelayanan bisnis, kapitalisasi modal dari berbagai sumber, dan ekspansi bisnis yang sudah berjalan.

Selanjutnya untuk melakukan implementasi strategi ini diperlukan elaborasi secara jelas, reasonable, sustainable dan impelementatif. Beberapa kegiatan ini meliputi antara lain adalah Identifikasi potensi bisnis, pelatihan Sumber daya manusia, pembentukan unit bisnis Masjid Nurul Iman yang tepat dan sesuai dengan daya dukung, peningkatan kerja sama bisnis dan pemanfaatan Aset Masjid Nurul Iman secara proporsional, selektif dan profesional.

Untuk merealisasikan usaha pemberdayaan umat melalui masjid maka pengurus Masjid Nurul Iman segera mendirikan baitul maal untuk pengembangan usaha baik yang berdimensi sosial, spiritual maupun ekonomi. Selain itu, pengurus Masjid Nurul Iman segera membangun bisnis makanan ringan sehat dan halal yang skalanya Mikro atau Ultra Mikro Dengan memperhatikan hasil dari pembahasan dan kesimpulan maka disarankan bahwa untuk pengembangan ekonomi Masjid Nurul Iman diperlukan beberapa hal, yaitu Perlu dilakukan identifiksai potensi ekonomi
Masjid Nurul Iman dengan tepat terutama dalam pembukaan bisnis baru untuk pengembangan perekonomian umat, Secepatnya dibangun bisnis baru untuk skala mikro misalnya penyewaaan ruangan dan pembukaan toko bahan pokok untuk kebutuhan jamaah.

Perlu pengembangan sumber daya manusia pengurus Masjid Nurul Iman agar pengurus siap dalam menjalankan usaha bisnisnya dengan profesional tanpa melanggar tata kelola secara Syariah.

Perlu dikembangkan inovasi dalam penyelenggaraan pendidikan terutama untuk Pendidikan Anak Usia Dini dan kursus ikutannya. Selain itu, perlu juga dikembangkan pembinaan untuk anak usia sekolah dasar. Terutama dalam hal pembentukan karakter. Dalam hal ini segera disusn rencana dan pola kerjasama dengan penyandang dana.

\section{REFERENSI}

Aisyah, Siti S. EI (2013). Membangun Kekuatan Ekonomi Masjid (Studi Kasus Masjid Taqwa Muhammadiyah Padang). Jurnal Syari'ah Vol. II, No. II, Oktober 2013

Almumayyaz (2014). Al Quran Tajwid Warna, Transliterasi Per Kata, Terjemah Per Kata. Cipta Bagus Segara. Bekasi. 
Anggraeni, Pratiwi, Sunarti M. Kholid, dan Mawardi (2017). Analisis SWOT pada UMKM Keripik Tempe Amel Malang dalam Rangka Meningkatkan Daya Saing Perusahaan. Jurnal Administrasi $\begin{array}{llll}\text { Bisnis } & \text { (JAB)|Vol. } & 43 & \text { No.1 }\end{array}$ Februari2017.

Ananda, Amin Dwi dan Dwi Susilowati (2017). Pengembangan Usaha Mikro Kecil dan Menengah (UMKM) Berbasis Industri Kreatif di Kota Malang. Jurnal Ilmu Ekonomi Vol X Jilid X/Tahun Hal. $120-142$. Universitas Muhammadiyah Malang.

Assidiq J, (2019): Jimly: Jangan Pisahkan Fungsi Ekonomi dari Masjid. Rabu 13 $\begin{array}{lll}\text { Feb } & 2019 \quad 20: 10 \quad \text { WIB. }\end{array}$ https://www.republika.co.id/berita/duni a-islam/islamnusantara/19/02/13/pmv8m8320-jimlyjangan-pisahkan-fungsi-ekonomi-darimasjid.

Ali, M, Zasri (2012). Masjid sebagai Pusat Pembinaan Umat. Jurnal Toleransi Media Ilmiah komunikasi Umat Beragama. Vol.4 No. 1 (2012). ISSN; 2086 - 0315 e-ISSN: 2407 - 1595

Dalmeri, (2014). Revitalisasi Fungsi Masjid sebagai Pusat Ekonomi dan Dakwah Multikultural. Jurnal Walisongo, Volume 22, Nomor 2, November 2014Universitas Indraprasta PGRI.

Darodjat dan Wahyudiana, (2014). Memfungsikan Masjid sebagai Pusat
Pendidikan untuk Membentuk Peradaban Islam. Jurnal Islamadina, Volume XIII, No. 2, Juli 2014: 1-13.

Erziaty, Rozzana (2015). Pemberdayaan Ekonomi Potensial Masjid sebagai Model Pengentasan Kemiskinan. Aliqtishadiyah, Jurnal Ekonomi Syariah dan Hukum Ekonomi Syariah. Volume: II, Nomor II. Juni 2015 Hal 82-98

Farida, Anik (2014). "Islamisasi Sains dan Saintifikasi Islam": Model Manajemen Pemberdayaan di Masjid Salman ITB Bandung. Jurnal Multikultural \& $\begin{array}{lllll}\text { Multireligius } & \text { Vol. } 13 & \text { No. } 1\end{array}$

HARMONI. Januari - April 2014

Fadlullah Muhammad Endy dan M. Amir Mahmud (2017). Pemberdayaan Ekonomi Jama'ah Masjid melalui Koperasi. Jurnal Lisan Al- Hal Volume 9, No. 2, Desember 2017” 361

Falah, Syahrul (2017). Pemberdayaan Ekonomi Masyarakat Ala Pondok Pesantren di Kelurahan Kejawan Putih Tambak Surabaya. Jurnal Ekonomi Syariah Teori dan Terapan Vol. 4 No. 4 April 2017: 340-352; 345

Ismowaty, Mary (2018). Analisis SWOT dalam Meningkatkan Program Jak Lingko. Program Pasca Sarjana Magister Ilmu Administrasi Institut Ilmu Sosial dan Manajemen STIAMI Indonesia, Jakarta.

Ismatullah, Ismet dan Tina Kartini (2018). Transparansi dan Akuntabilitas Dana 
Masjid Dalam Pemberdayaan Ekonomi

Ummat. Jurnal Ilmiah Ilmu Ekonomi Page 186. ISSN 2088 6969. Vol.6 Edisi 12, Mar 2018.

Kasdi, Abdurrohman (2016). Filantropi Islam

Untuk Pemberdayaan Ekonomi Umat (Model Pemberdayaan ZISWAF di BMT Se-Kabupaten Demak). IQTISHADIA Vol. 9, No. 2, 2016, 227 245 P-ISSN: 1979-0724, E-ISSN: 2502-3993.

. Muthalib, Ahmad Abdul (2018). Prospek Pemberdayaan Ekonomi Masyarakat Berbasis Masjid di Kota Watampone. Jurnal Iqtisudana. Volume 4 Nomor 1 Ed. Juni 2018.

Muslim, Azis (2014). Pemberdayaan Ekonomi Masyarakat Berbasis Masjid (Studi Kasus di Masjid Baiturrahman Klidon Sinduharjo Ngaglik Sleman). Jurnal Ilmu Dakwah. Vol 34, No 2.

Murdani, Sus Widayani, dan Hadromi. (2019). Pengembangan Ekonomi Masyarakat Melalui Pemberdayaan Usaha Mikro Kecil dan Menengah (Studi di Kelurahan Kandri Kecamatan Gunungpati Kota Semarang). ABDIMAS, Jurnal Pengabdian kepada Masyarakat. 23(23) (2019): 152-157.

Nurjamilah, Cucu (2016). Pemberdayaan Masyarakat Berbasis Masjid dalam Perspektif Dakwah Nabi SAW. Journal of Islamic Studies and Humanities Vol.
Nuriyanto, Lilam Kadarin (2018). Pengaruh Pengelolaan Masjid terhadap Pemberdayaan Umat di Kota Surabaya. Jurnal Bimas Islam Vol.11. No. IV 2018

Rangkuti, Freddy, (2003). Analisis Swot Teknik Membedah Kasus Bisnis. Reorientasi Konsep Perencanaan Strategis untuk Menghadapi Abad 21. Gramedia. Jakarta 2003.

Rais, Amien, M (1999). Kritik Islam Terhadap Kapitalisme dan Sosialisme.

Dalam Sekitar Kemiskinan dan Keadilan, Dari Cendikiawan Kita Tentang Islam. Penerbit Universitas Indonesia, UI - Press. Jakarta.

Rahardja, Prathama dan Mndala Manurung, (2010). Teori Ekonomi Mikro. Lembaga Penerbit Fakultas Ekonomi Universitas Indonesia. Jakarta.

Ridwanullah, Ade Iwan dan Dedi Herdiana (2018). Optimalisasi Pemberdayaan Masyarakat Berbasis Masjid. Ilmu Dakwah : Academic Journal for Homiletic Studies Volume 12 Nomor 1 (2018) 82-98.

Ramadhan, Abdurrahman, Idaul Hasanah dan Rahmad Hakim. (2019) Potret Masjid Sebagai Basis Pemberdayaan Ekonomi Umat. Iqitishodia: Jurnal Ekonomi Syariah ISSN (Print): 2503-118X ISSN (Online): 2580-4669 Vol. 4, No. 1 (Maret 2019), pp. 31-49

1, No. 1 (2016) 93-119. 
Suwarto, (2012). Peranan Masjid dalam Pengembangan Ekonomi Masyarakat di Masjid Riyad Surakarta (Tinjauan Sosiologi Agama). Skripsi Universitas Muhammadiyah Surakarta.

Supriyadi, Ahmad (2017). Pemberdayaan Ekonomi Berbasis Masjid (Studi Kritis pasal 53, 54, dan 55 PP. Nomor 14 tahun 2014 tentang Pelaksanakaan UU Nomor 23 tahun 2011 tentang Pengelolaan Zakat. AN-NISBAH, Vol. 03, No. 02, April 2017.

Saefudin, AM (1999). Sistem Sosial Ekonomi Islam, Dalam Sekitar Kemiskinan dan Keadilan, Dari Cendikiawan Kita Tentang Islam. Penerbit Universitas Indonesia, UI - Press. Jakarta.

Sugiyono (2011). Metode Penelitian Kuantitatifm dan Kualitatif dan R \& D. Alfabeta Bandung

Suryanto Asep and Asep Saepulloh, (2016).

Optimalisasi Fungsi dan Potensi Masjid Model Pemberdayaan Ekonomi Masyarakat Berbasis Masjid di Kota Tasikmalaya. Jurnal Iqtishoduna, Vol. 8 No. 2 Oktober 2016 ISSN: 2252 5661, e - ISSN: $2443-0056$

Emerging Markets Vol. 3 No. 1 P. 27-42, April 2011. Malaysia: Sultan Agung Islamic University.

Wiroso. (2011). Akuntansi Transaksi Syariah. Jakarta: Ikatan Akuntan Indonesia.
Zainul Arifin. (2006). Memahami Bank Syariah, Lengkap, Peluang, Tantangan, dan Prospek. Jakarta: Alfabeta. 